\title{
Imidatsolinonit- vaihtoehto rypsin ja rapsin rikkakasvien torjuntaan
}

\author{
Anna-Leena Haukkapää, Mervi Seppänen ja Unto Tulisalo \\ Soveltavan biologian laitos, Latokartanonkaari 5, PL27, 00014 Helsingin yliopisto, \\ anna-leena.haukkapaa@helsinki.fi
}

\section{Tiivistelmä}

Rypsin ja rapsin viljelyyn ei ole toistaiseksi löytynyt tehokasta rikkakasvien torjuntamenetelmää. Trifluraliinin käyttöä öljykasvien rikkatorjunnassa rajoittaa sen maalaji- ja sääriippuvuus sekä käyttötapa kylvömuokkauksen yhteydessä. Trifluraliinia ei myöskään voi käyttää suorakylvön yhteydessä. Uuden vaihtoehdon tarjoavat imidatsolinoni-herbisidinkestävät lajikkeet. Rypsi ja rapsi eivät ole luonnostaan kestäviä imidatsolinoneille, mutta niihin voidaan siirtää luonnon mutaatioista löydetyt kaksi kestävyysgeeniä perinteisellä takaisinristeytysmenetelmällä. IMI-resistentit rapsilajikkeet ovat nykypäivää esimerkiksi PohjoisAmerikassa.

Imidatsolinonit (IMI:t) ovat herbisidejä, jotka sulfonyyliureoiden tavoin ehkäisevät asetolaktaattisyntetaasi-entsyymin (ALS) toimintaa. Ne tehoavat hyvin useisiin leveälehtisiin rikkakasveihin ja yksisirkkaisiin heiniin. Suomessa tehdyissä herbisidikokeissa niiden teho öljykasvipeltojen pahimpiin rikkakasveihin, jauhosavikkaan, peltomataraan ja pihatähtimöön, oli erittäin hyvä tai hyvä. IMI-herbisidien käyttöä puoltaa myös se, että käsittely voidaan tehdä vasta taimivaiheessa, jolloin todellinen torjuntatarve on jo tiedossa. Tärkeänä etuna IMI-herbisidien käytössä on myös niiden alhainen myrkyllisyys ihmisille.

IMI-resistenssiä aiheuttaa rapsilla kaksi semidominoivaa geeniä, pm1 ja pm2. Rapsilla molempien geenien läsnäolo on edellytyksenä kunnolliselle torjunta-ainekestävyydelle, mutta näyttäisi siltä, että rypsillä riittää vain pm2-geenin läsnäolo. Lisätutkimusta asiasta kuitenkin tarvitaan. Olemme tutkimuksessamme onnistuneet siirtämään IMI-kestävyyteen tarvittavat molemmat geenit Suomessa menestyviin aikaisiin rapsilinjoihin. Rypsillä takaisinristeytystyö jatkuu, mutta alustavien DNA-tutkimusten perusteella ainakin pm2-geeni on onnistuttu siirtämään eräisiin suomalaisiin rypsilinjoihin.

IMI-resistentit rypsi- ja rapsilajikkeet tarjoavat käyttökelpoisen vaihtoehdon rikkakasvien torjuntaan tulevina vuosina, koska glyfosaatti- ja glufosinaattikestävät lajikkeet eivät todennäköisesti GMOvastustuksen vuoksi Suomeen lähiaikoina rantaudu. Toimiva rypsi- ja rapsipeltojen rikkakasvien torjunta olisi yksi tärkeimmistä öljykasvien viljelyä edistävistä ja ylläpitävistä toimenpiteistä nykyisessä viljelykasvien keskinäisessä markkinakilpailussa.

\author{
Asiasanat \\ Imidatsolinonit, IMI-resistenssi, rypsi, rapsi
}




\section{Johdanto}

Rypsi (Brassica rapa) ja rapsi (Brassica napus) ovat merkittäviä kasveja suomalaisessa kasvinviljelyssä. Niiden pääasiallisin käyttökohde on elintarviketeollisuus, mutta myös nonfood-käyttö lisääntyvän biopolttoaineiden kiinnostuksen myötä on kasvamassa. Rypsillä ja rapsilla on erinomainen esikasviarvo, mikä korostuu etenkin viljanviljelytiloilla. Rypsin ja rapsin viljelyala on ollut Suomessa viime vuosina keskimäärin 60000 hehtaaria (Maa- ja metsätalousministeriö 2003).

Öljypuristamoteollisuudella on vastaanotetulle siemenelle tietyt laatukriteerit, jotta saataisiin tuotettua laadukasta öljyä ja rehua. Yhtenä kriteerinä on alhainen rikkapitoisuus, sillä rikkasiemenet sekä alentavat öljyn laatua että vaikeuttavat sen prosessointia. Alhaisen rikkapitoisuuden saavuttaminen on nykyisin entistä vaikeampaa tehokkaiden torjunta-aineiden puuttuessa. Öljykasvien rikkakasviongelma edellyttääkin joko kokonaan uusien torjunta-aineiden kehittämistä tai rypsin ja rapsin kestävyyden parantamista sellaisiin torjunta-aineisiin, jotka tehoavat hyvin öljykasvipellon rikkakasveihin.

Rikkakasvien torjunta rypsillä ja rapsilla nojaa tällä hetkellä trifluraliinin käyttöön, joka kuitenkin todennäköisesti on jäämässä pois markkinoilta. Jo muutamien vuosien ajan Kanadassa on käytetty kevätöljykasvien rikkakasvien torjuntaan imidatsolinoneja (IMI), jotka sulfonyyliureoiden tavoin ehkäisevät asetolaktaattisyntetaasi-entsyymin (ALS) toimintaa (Shaner ym. 1984). Ne tehoavat hyvin useisiin leveälehtisiin rikkakasveihin ja yksisirkkaisiin heiniin. IMI-käsittely voidaan tehdä vasta taimivaiheessa, jolloin todellinen torjuntatarve on jo tiedossa. Tärkeänä etuna IMI-herbisidien käytössä on myös niiden alhainen myrkyllisyys ihmiselle sekä alhaiset käyttömäärät (Mazur ym. 1987, Bernasconi ym. 1995).

Rypsi ja rapsi eivät ole luonnostaan kestäviä IMI-herbisideille. Kevätrapsiin on kuitenkin jalostettu kestävyys IMI-herbisidejä vastaan luontaisia kestävyysmutaatioita käyttäen (Swanson ym. 1989). Kyseessä ei tällöin ole geneettisesti muunneltu lajike. IMI-resistentit rypsi- ja rapsilajikkeet voivat tarjota käyttökelpoisen vaihtoehdon rikkakasvien torjuntaan tulevina vuosina myös Suomessa.

Pääasiassa Maa- ja metsätalousministeriön rahoittaman hankkeen tavoitteena oli ensinnäkin tutkia IMI-herbisidin (imazamox) vaikutusta Suomen öljykasvipelloilla esiintyviin rikkakasveihin sekä määrittää vaadittava tehoainepitoisuus. Toisena tavoitteena oli siirtää IMI-kestävyys suomalaisiin, aikaisiin rypsi- ja rapsilinjoihin. Alkuperäisenä tavoitteena oli lisäksi tarkoitus tutkia mahdollisen rikkakasviresistenssin kehittymistä, mutta vaikean toteutettavuutensa vuoksi tämä kuitenkin jätettiin pois.

\section{Aineisto ja menetelmät}

\section{Herbisidikokeet}

IMI-herbisidin vaikutusta eri rikkakasveihin sekä vaadittavaa tehoainepitoisuutta tutkittiin herbisidikokeiden avulla. Samalla havainnoitiin rapsin IMI-kestävyyttä. Kokeet järjestettiin vuonna 2002 Tuusulassa ja Jokioisissa sekä vuonna 2003 Helsingissä ja Jokioisissa. Kokeissa käytettiin kanadalaisia IMI-resistenttejä rapsilajikkeita. Koemallina oli satunnaistetut lohkot ja kerranteita kokeissa oli joko kolme tai neljä. Koejäseninä olivat käsittelemättömän kontrollin lisäksi neljä imazamox-käsittelyä: IMI $30 \mathrm{~g}$ ai ha ${ }^{-1}+$ Super Biokiinnite 0,25\% (v/v), IMI $30 \mathrm{~g}_{\text {ai ha }}{ }^{-1}$, IMI $40 \mathrm{~g}_{\text {ai }} \mathrm{ha}^{-1}+$ Super Biokiinnite $0,25 \%$ (v/v) ja IMI $60 \mathrm{~g}$ ai $\mathrm{ha}^{-1}+$ Super Biokiinnite $0,25 \%$ (v/v). Imazamox-herbisidin vaikutus eri rikkakasveihin määritettiin rikkakasvilaskentojen, kuiva-ainemääritysten, puhtausmääritysten sekä visuaalisten havaintojen avulla. IMI-rapsin kestävyys imazamoxia vastaan arvioitiin visuaalisten havaintojen ja satotulosten perusteella. Lisäksi satosiemenestä määritettiin rasvahappo- ja öljypitoisuudet sekä tuhannen siemenen paino (tsp). Kaikkien havaintojen ja määritysten perusteella arvioitiin sopiva tehoaineen käyttömäärä.

Sadosta, rikkakasvien kokonaismäärästä, rikkakasvien kokonaiskuivapainosta sekä jauhosavikan, linnunkaalin ja pelto-orvokin määristä ja kuivapainoista tehtiin tilastolliset analyysit käyttämällä SAS/STAT- ohjelman MIXED- menetelmää (Littell ym. 1996). P-arvoltaan < 0,05 tulokset arvioitiin tilastollisesti merkitseviksi. Kasvuaikahavainnoista (Tuusula 2002 ja Helsinki 2003) tehtiin varianssianalyysit käyttämällä Agrobase ${ }^{\mathrm{TM}}$ - ohjelmaa (Mulitze 1991). 


\section{IMI-kestävyyden risteyttäminen rypsi- ja rapsilinjoihin}

IMI-kestävyyden siirto suomalaisiin rypsi- ja rapsilinjoihin tapahtui perinteisellä takaisinristeytysmenetelmällä Helsingin yliopiston Viikin kasvihuoneissa vuosina 2002-2005. IMI-kestävyyteen vaikuttaa kaksi semidominoivaa geeniä, pm1 ja pm2. Riittävän IMI-kestävyyden saavuttamiseksi molempien geenien tulisi olla läsnä ainakin rapsilla. Rapsilla takaisinristeytysten määräksi riitti neljä, kun taas rypsillä risteytyksiä vaadittiin kuusi. Jokainen takaisinristeytyssukupolvi käsiteltiin imazamoxilla 3-4-lehtivaiheessa (BBCH 13-14) (Hack ym. 1992), minkä jälkeen jatkoon valittiin vain parhaiten säilyneet ja elinvoimaisimmat yksilöt, eli siis ne, jotka todennäköisimmin sisälsivät molemmat IMI-kestävyyteen vaikuttavat geenit. Lopullinen varmistus geenien läsnäolosta tehtiin takaisinristeytysten jälkeen, jolloin DNAnäytteistä määritettiin pm1- ja pm2-geenien läsnäolo. Määritykset tehtiin kanadalaisessa laboratoriossa.

\section{Tulokset ja tulosten tarkastelu}

\section{Herbisidikokeet}

Kokeissa käytetty IMI-resistentti rapsilajike kesti hyvin korkeimmankin imazamox- määän, $60 \mathrm{~g}$ ai ha ${ }^{-1}$. Käsittelyn jälkeisinä päivinä esiintyi hieman kloroottisuutta, mutta se tasoittui muutamassa päivässä. IMIkäsittelyillä ei niin ikään ollut negatiivista vaikutusta satoon (Taulukko 1.) eikä myöskään öljyn laatu muuttunut (Haukkapää ym. 2005).

Taulukko1. Herbisidikokeiden satotulokset $(\mathrm{kg} / \mathrm{ha})$ ja niiden tilastolliset merkitsevyydet $* * *(\mathrm{P}<0,001), * *(\mathrm{P}<0,01)$, * $(\mathrm{P}<0,05)$ ja o $(\mathrm{P}<0,10)$ (Haukkapää ym. 2005).

\begin{tabular}{|c|c|}
\hline Käsittely & $\begin{array}{l}\text { Sato }^{\mathrm{a}} \\
\mathrm{kg} / \mathrm{ha}\end{array}$ \\
\hline \multicolumn{2}{|l|}{ Tuusula 2002} \\
\hline Käsittelemätön & 3193 \\
\hline Imazamox $60 \mathrm{~g}$ ai ha ${ }^{-1}+$ kiinnite & 3130 \\
\hline Imazamox $40 \mathrm{~g}$ ai ha ${ }^{-1}+$ kiinnite & 3172 \\
\hline Imazamox $30 \mathrm{~g}$ ai ha ${ }^{-1}+$ kiinnite & 3210 \\
\hline Imazamox $30 \mathrm{~g}$ ai ha $^{-1}$ & 3246 \\
\hline \multicolumn{2}{|l|}{ Jokioinen 2002} \\
\hline Käsittelemätön & 399 \\
\hline Imazamox $60 \mathrm{~g}$ ai ha ${ }^{-1}+$ kiinnite & $1210 * * *$ \\
\hline Imazamox $40 \mathrm{~g}$ ai ha ${ }^{-1}+$ kiinnite & $1081 * * *$ \\
\hline Imazamox $30 \mathrm{~g}$ ai ha ${ }^{-1}+$ kiinnite & $983 * * *$ \\
\hline Imazamox $30 \mathrm{~g} \mathrm{ai} \mathrm{ha}^{-1}$ & $971 * * *$ \\
\hline \multicolumn{2}{|l|}{ Helsinki 2003} \\
\hline Käsittelemätön & 2712 \\
\hline Imazamox $60 \mathrm{~g}$ ai ha ${ }^{-1}+$ kiinnite & 2574 \\
\hline Imazamox $40 \mathrm{~g}$ ai ha ${ }^{-1}+$ kiinnite & $2372 *$ \\
\hline Imazamox $30 \mathrm{~g}$ i ha ${ }^{-1}+$ kiinnite & 2650 \\
\hline Imazamox $30 \mathrm{~g} \mathrm{ai} \mathrm{ha}^{-1}$ & 2577 \\
\hline \multicolumn{2}{|l|}{ Jokioinen 2003} \\
\hline Käsittelemätön & 2092 \\
\hline Imazamox $60 \mathrm{~g}$ ai ha ${ }^{-1}+$ kiinnite & $2366^{*}$ \\
\hline Imazamox $40 \mathrm{~g}$ ai ha ${ }^{-1}+$ kiinnite & $2346^{*}$ \\
\hline Imazamox $30 \mathrm{~g}$ ai ha ${ }^{-1}+$ kiinnite & 22840 \\
\hline Imazamox $30 \mathrm{~g}$ ai ha ${ }^{-1}$ & $2433 * *$ \\
\hline
\end{tabular}


Imazamox tehosi hyvin useisiin leveälehtisiin rikkakasveihin (Taulukko 2.). Parhaiten se tehosi öljykasvipeltojen pahimpiin rikkakasveihin, jauhosavikkaan, peltomataraan ja pihatähtimöön, kun taas peltoorvokkiin, linnunkaaliin ja kiertotattareen imazamox ei tehonnut riittävästi (Haukkapää ym. 2005). Imazamoxin on aikaisemmissa tutkimuksissa todettu tehoavan hyvin myös useisiin yksisirkkaisiin heiniin, kuten esimerkiksi hukkakauraan (Harker ym. 2000, Monaco ym. 2002). Näissä kokeissa sen vaikutusta heiniin ei kuitenkaan määritetty.

Taulukko 2. Rikkakasvien kokonaislukumäärä $\left(\mathrm{kpl} / \mathrm{m}^{2}\right)$ ja kokonaiskuivapaino $\left(\mathrm{g} / \mathrm{m}^{2}\right)$ sekä niiden tilastolliset merkitsevyydet $* * *(\mathrm{P}<0,001), * *(\mathrm{P}<0,01), *(\mathrm{P}<0,05)$ ja o $(\mathrm{P}<0,10)$ (Haukkapää ym. 2005).

\begin{tabular}{|c|c|c|}
\hline Käsittely & $\begin{array}{l}\text { Rikkakasvien } \\
\text { kokonaislukumäärä } \\
\mathrm{kpl} / \mathrm{m}^{2}\end{array}$ & $\begin{array}{l}\text { Rikkakasvien } \\
\text { kokonaiskuivapaino } \\
\mathrm{g} / \mathrm{m}^{2}\end{array}$ \\
\hline \multicolumn{3}{|l|}{ Tuusula 2002} \\
\hline Käsittelemätön & 340 & 36,3 \\
\hline Imazamox $60 \mathrm{~g}$ ai ha ${ }^{-1}+$ kiinnite & 310 & $14,4 * *$ \\
\hline Imazamox $40 \mathrm{~g}$ ai ha ${ }^{-1}+$ kiinnite & 260 & $10,2 * * *$ \\
\hline Imazamox $30 \mathrm{~g}$ ai ha ${ }^{-1}+$ kiinnite & 294 & $11,7 * * *$ \\
\hline Imazamox $30 \mathrm{~g}$ ai ha $^{-1}$ & 214 & $10,7 * * *$ \\
\hline \multicolumn{3}{|l|}{ Jokioinen 2002} \\
\hline Käsittelemätön & 1139 & 326,3 \\
\hline Imazamox $60 \mathrm{~g}$ ai ha ${ }^{-1}+$ kiinnite & $187 * * *$ & $9,6 * * *$ \\
\hline Imazamox $40 \mathrm{~g}$ ai ha $^{-1}+$ kiinnite & $391 * * *$ & $21,8 * * *$ \\
\hline Imazamox $30 \mathrm{~g}$ ai ha $^{-1}+$ kiinnite & $591 * * *$ & $39,8 * * *$ \\
\hline Imazamox $30 \mathrm{~g}$ ai ha $^{-1}$ & $887 *$ & $70,6 * * *$ \\
\hline \multicolumn{3}{|l|}{ Helsinki 2003} \\
\hline Käsittelemätön & 27 & 22,64 \\
\hline Imazamox $60 \mathrm{~g}$ ai ha ${ }^{-1}+$ kiinnite & $5 * *$ & $0,12 *$ \\
\hline Imazamox $40 \mathrm{~g}$ ai ha ${ }^{-1}+$ kiinnite & $7 * *$ & $1,09 *$ \\
\hline Imazamox $30 \mathrm{~g}$ ai ha ${ }^{-1}+$ kiinnite & $8 * *$ & $3,96^{*}$ \\
\hline Imazamox $30 \mathrm{~g} \mathrm{ai} \mathrm{ha}^{-1}$ & $10 * *$ & $5,70 *$ \\
\hline \multicolumn{3}{|l|}{ Jokioinen 2003} \\
\hline Käsittelemätön & 134 & 39,0 \\
\hline Imazamox $60 \mathrm{~g}$ ai ha ${ }^{-1}+$ kiinnite & $34 * * *$ & $1,6 * * *$ \\
\hline Imazamox $40 \mathrm{~g}$ ai ha ${ }^{-1}+$ kiinnite & $51 * * *$ & $3,4 * * *$ \\
\hline Imazamox $30 \mathrm{~g}$ ai ha ${ }^{-1}+$ kiinnite & $67 * * *$ & $3,9 * * *$ \\
\hline Imazamox $30 \mathrm{~g}$ ai ha ${ }^{-1}$ & $77 * *$ & $4,9 * * *$ \\
\hline
\end{tabular}

Kaikkein optimaalisimmaksi imazamoxin käyttömääräksi arvioitiin $40 \mathrm{~g}$ ai ha ${ }^{-1}$. Se antoi riittävän tehon useisiin ölykasvipeltojen ongelmallisiin kaksisirkkaisiin rikkakasveihin, mutta ei kuitenkaan vioittanut rapsikasvustoa.

Herbisidikokeiden tarkemmat tulokset on esitetty seuraavassa julkaistavaksi hyväksytyssä artikkelissa: Haukkapää ym. 2005. Effect of imazamox in imidazolinone-resistant spring oilseed rape in Finland, Agricultural and Food Science vol. 14, no. 4, 2005 (ilmestyy helmikuussa 2006).

\section{IMI-kestävyyden risteyttäminen rypsi-ja rapsilinjoihin}

Molemmat IMI-kestävyyteen vaikuttavat geenit, pm1 ja pm2, onnistuttiin risteyttämään viiteen aikaiseen, suomalaiseen rapsilinjaan. Näistä valittiin jatkoon viljelyominaisuuksiltaan kaksi parhainta linjaa, jotka ovat nyt valmiina lisäyksiä ja lajikekokeita varten. 
Molempien IMI-kestävyysgeenien saaminen samaan rypsilinjaan osoittautuikin vaikeaksi toteuttaa. Pm2-geeni saatiin siirrettyä kahteen eri rypsilinjaan, kun taas pm1-geeni onnistuttiin risteyttämään vain yhteen. Alustavien tutkimusten perusteella näyttäisi kuitenkin siltä, että pelkän pm2-geenin läsnäolo rypsissä riittäisi antamaan tarvittavan kestävyyden IMI-herbisidiä vastaan. Lisätutkimuksia asiasta kuitenkin tarvitaan. Toisena vaihtoehtona on risteyttää eri kestävyysgeenit omaavat rypsilinjat keskenään. Molempien geenien saaminen samaan rypsilinjaan olisi tällöin todennäköisesti helpompaa, sillä molemmat geenit ovat jo valmiina rypsissä.

\section{Johtopäätökset}

Herbisidikokeiden tulosten perusteella voidaan sanoa, että IMI-kestävät rypsi- ja rapsilajikkeet sekä imazamox ovat hyvä vaihtoehto Suomen öljykasvipeltojen rikkakasvien torjuntaan. Tästä syystä IMIresistenssin siirto Suomessa menestyviin rypsi- ja rapsilinjoihin on ollut perusteltua. Jatkotutkimukset tulisi suunnata pelkän pm2-geenin riittävyyteen rypsillä sekä pm1- ja pm2-geenien saamiseen samaan rypsilinjaan.

\section{Kirjallisuus}

Bernasconi, P., Woodworth, A.R., Rosen, B.A., Subramanian, M.V. \& Siehl, D.L. 1995. A naturally occurring point mutation confers broad range tolerance to herbicides that target acetolactate synthase. The Journal of Biological Chemistry 270: 17381-17385.

Hack, H., Bleiholder, H., Buhr, L., Meier, U., Schnock-Fricke, U., Weber, E. \& Witzenberger, A. 1992. A uniform code for phenological growth stages of mono- and dicotyledonous plants. Extended BBCH scale, general. Nachrichtenblatt des Deutchen Pflanzenschutzdienstes 44: 265-270.

Harker, K.N., Blackshaw, R.E., Kirkland, K.J., Derksen, D.A. \& Wall, D. 2000. Herbicide-tolerant canola: weed control and yield comparisons in Western Canada. Canadian Journal of Plant Science 80: 647-654.

Haukkapää, A-L., Junnila, S., Eriksson, C., Tulisalo, U. \& Seppänen, M. 2005. Efficacy of imazamox in imidazolinone-resistant spring oilseed rape in Finland. Agricultural and Food Science vol. 14, no. 4, (ilmestyy helmikuussa 2006).

Little, R.C., Milliken, G.A., Stroup, W.W. \& Wolfinger, R.D. 1996. SAS System for Mixed Models. Cary, NC: SAS institute Inc. $633 \mathrm{~s}$.

Maa- ja metsätalousministeriö 2003. Öljykasvistrategia. Työryhmämuistio MMM 2003: 8, 53 s.

Mazur, B.J., Chui, C.F. \& Smith, J.K. 1987. Isolation and characterization of plant genes coding for acetolactate synthase, the target enzyme for two classes of herbicides. Plant Physiology 85: 1110-1117.

Monaco, T.J., Weller, S.C. \& Ashton, F.M. 2002. Weed science- principles and practices. 4. painos. Johnwiley \& Sons Inc., New York, $671 \mathrm{~s}$.

Mulitze, D.K. 1991. Agrobase/4TM, version 1.1, Reference Manual, Agronomix Software Inc., Manitoba, Canada. $257 \mathrm{~s}$.

Shaner, D.L., Anderson, P.C. \& Stidham, M.A. 1984. Imidazolinones- potent inhibitors of acetohydroxyacid synthase. Plant Physiology 76: 545-546.

Swanson, E.B., Herrgesell, M.J., Arnoldo, M., Sippell, D.W. \& Wong, R.S.C. 1989. Microspore mutagenesis and selection: Canola plants with field tolerance to the imidazolinones. Theoretical and Applied Genetics 78: 525-530. 